\title{
Draconian and manifestly unjust: how the confiscation regime has developed
}

by Sir Ivan Lawrence QC

The article is taken from a speech on the law of confiscation given by the author at the 26th Cambridge International Symposium on Economic Crime at Jesus College, Cambridge, on September 5, 2008.

I have been practising at the English Criminal Bar for 46 years, and for 23 of them I was a British MP, concerning myself with the modernisation and improvement of British criminal justice - of which I have always felt very proud. Whether it is the best in the world I cannot say, but it has certainly been universally admired and copied by many countries.

At its heart has been the doctrine of the rule of law. This has been anchored to the concepts of fairness and justice, with its judges, juries and barristers standing firmly against oppression by the state and its sometimes harsh laws, whenever it threatens the liberty of the citizen. That is why, before anyone can be convicted of crime and deprived of that liberty, the state must satisfy ordinary jurymen and women (or lay magistrates drawn from and representing ordinary people), of that person's guilt beyond reasonable doubt. That is why our judges, who have risen through the ranks of the lawyers practising daily in our courts, are imbued through every fibre of their judicial being with the traditional principles of our common law, and so have been able to use their own judgment or discretion when they perceive any risk of injustice.

How then has it come about that a person convicted of a crime involving financial benefit, has now been subjected by Parliament, since the Proceeds of Crime Act 2002, to a law more draconian and manifestly unjust than anything ever devised by the state in modern times? This is the law, which now applies to what are called - erroneously confiscation proceedings.

It is difficult to have any sympathy for financial criminals whose greed has led them to deprive their fellow citizens of their hard- earned money. Indeed when I was first invited to make a keynote speech at this the annual Cambridge International Symposium on Economic Crime 14 years ago, I suggested that if we wanted to do something which would seriously reduce crime, the courts, instead of just imprisoning serious offenders, should deprive more of them of the money (or their criminally funded possessions) that they had derived from their crimes. I was a sponsor of the Private Members' Bill adopted by the Government which extended the existing confiscation regime from drug offences to other crimes, and as Chairman of the Commons Home Affairs Select Committee I proposed that our confiscation laws should be improved, extended, and internationalised.

But I never envisaged - and nor, I think, did anyone else that when we came to develop those laws against fraudsters and money-launderers, and to strengthen them against drug-traffickers and other illegal money-makers, that those laws would be manifestly unjust. Principally, It is one thing to punish an offender and also to deprive him of the proceeds of his crime; it is quite another to deprive him of property that is not the proceeds of crime. To put it another way, it is one thing to punish a man severely for his crime; it is quite another to punish him severely twice for the same offence. Yet the Proceeds of Crime Act 2002 perpetrates that injustice. As one eminent legal commentator, has said of the laws that Parliament has since passed: “These new laws appear to occupy some parallel legal universe which has no apparent relationship with the normal rules of criminal process.”

Under this statute, once a person has been convicted of fraud, and sent to prison, for perhaps several years, he or she can receive an additional prison sentence of up to 10 years if he or she fails to pay up whatever the court later assesses to be the benefit from the crime (for ease of style I will use the male gender hereafter when referring to the offender). There can be little wrong with such an additional punishment as long as the money assessed actually is his ill-gotten gain, and can still be retrieved from wherever the offender has hidden it. But it is how that benefit is assessed under the new law that is so manifestly unjust. 


\section{REQUIREMENT TO REBUT “CRIMINAL LIFESTYLE” ASSUMPTION}

To begin with, even where someone of hitherto good character is convicted of only one financial offence, the court is obliged to make an assumption that he has been living a "criminal lifestyle" for six years. As a result, all of the sources of his income and the money the convicted person has invested, even those that have been perfectly legitimate, in addition to money processed since conviction and up to the confiscation proceedings, are deemed to be "criminal money" and must be seized. Furthermore, no-one else who has received any of that "benefit" has any right to it. So if the convicted person has bought a house for himself or his wife and family, or a business, or a car, or gifted money to his children over those six years and since the trial out of money legitimately obtained, he and they will lose those acquisitions or gifts or whatever they are worth. As I have said, if they are truly the proceeds of ill-gotten gains then it is not unfair that the convicted person and his family should suffer in that wayhe should not have committed crime and should have thought about the consequences for his family. But what if he is not a thorough-going criminal and his only crime was in truth the one for which he was convicted and sentenced? The injustice is that under the new law the "criminal lifestyle" assumption still has to be made - unless he can rebut that assumption.

The trouble with requiring the offender to rebut that assumption, even to the lesser standard of probability, is that an innocent person may be in no position to discharge such a burden. Even a good and efficient businessman, engaged in honest trade in this country, may not be able to find supporting witnesses if his trading partners have died or gone to live somewhere untraceable in the South of France and cannot be found. As for an honest but less than efficient businessman, who has not kept perfect records or who may have lost them when his computer was stolen or who, through no fault of his own, happens to have some dodgy customers - proving that his income was innocent may be impossible. Or what of an international businessman dealing in mobile phones, who can identify the foreign business associates he wants and needs to call to give evidence of his honesty, but who cannot do so because they have no desire to come to this country lest they too be arrested because of their business association with a man convicted of financial crime. Left alone without witnesses, what chance has anyone got of persuading a court that his denial of living a "criminal lifestyle" is believable, once he has been found guilty by a jury or has admitted to some act of serious dishonesty?

It is not only the transfer of the burden of proof, and the assumption that accompanies it, which are so contrary to the established precepts of British law. Because confiscation proceedings have been held not to be penal and the resulting deprivation of property is not a fine, the defendant is deprived of the protections he would otherwise receive from criminal proceedings. The prosecution is able to rely on evidence to prove that the defendant has benefitted from ill-gotten gains that would be inadmissible in a normal criminal court! Reliance can be placed by the court on the investigating officer's section 16 statement, which may contain what was said in a co-defendant's interview not in the presence of this defendant. Contested witness statements can be accepted as evidence. Even what the investigating officer may have picked up as hearsay "information" from someone along the way is admissible!

\section{PROPORTIONALITY AND DISCRETION}

It gets worse! If someone is part of a gang defrauding social welfare of $£ 1$ million over a period of time, and whose personal benefit has actually only been $£ 400$-for which crime he might not even have been sent to prison - he may now be held to have benefitted from the entire $£ 1$ million. And, if the court accepts the prosecution allegation that he must have that money hidden away somewhere, and he fails to pay the $£ 1$ million, he could go to prison for 10 years! In one recent case involving a fraud of $£ 3.2$ million, 16 fraudsters had jointly invented bogus companies and dishonestly pretended that they had paid VAT when they had not done so. They were not required to pay back the $£ 3.2$ million between them - which, on top of their sentence of imprisonment, would have been fair enough but EACH had to pay back $£ 3.2$ million; a total of $£ 51$ million representing sixteen times the amount lost. If they did not have that amount in their possession, or anything like it, they potentially faced ending up in prison for an additional 10 years.

In another of the most recent cases, the defendant was a pharmacist who had over-reclaimed $£ 464$ out of a total claim of $£ 212,464$, and the confiscation order made by the Crown Court in the total sum of $£ 212,464$ was only cancelled because the Court of Appeal was able to find that there had been an abuse of process.

Such a draconian statute surely plays havoc with the concept of proportionality and the European Convention's right to peaceful enjoyment of a person's possessions? Yet it is doubtful whether recourse to the European Court of Human Rights could be afforded by any defendant who had been stripped of all his money, or that even if it did get to that court, that it could be relied upon to put these matters right.

Traditionally, under our criminal justice system, the judge has nearly always had discretion before he sentences someone: he can use his common sense. But under this statute, because confiscation is not considered to be penal and therefore as an additional sentence passed upon a defendant, judicial discretion has been stripped away so that, apart from where abuse of process can be found, it is practically non-existent. If, for example, a defendant has, before trial, handed back to the loser all of his ill-gotten gains, the judge now has no discretion to take that into 
consideration before he makes the confiscation order. Unusually, the Proceeds of Crime Act 2002 is quite clear on judicial discretion and the appeal courts have held that it cannot be interpreted away to make room for such an absurd element as common sense!

In fact the whole system seems to be geared against a defendant in confiscation proceedings, for he may not be able to properly prepare his defence. For a serious financial crime, he is likely on conviction to have been sentenced to prison. If so, he will have little or no access to a computer, so necessary in a complicated case, and all his business files of documents will have been removed by HM Revenue and Customs during the trial and not returned to him. Furthermore, the prison system is in such a state that he may be having to share a cell with other noisy and distracting prisoners, he may not be allowed to have more than one meeting a week with his legal advisers and that for only a limited time, and he may find himself having to share a conference room with the visiting families of other prisoners, having to shout against their noise and that of reversing lorries outside the window of his conference room. I speak from just such experience! What chance in such circumstances has a defendant of concentrating on documentary detail and explanations, still less of proving anything against the odds to the satisfaction of a court?

\section{OTHER INJUSTICES}

Inevitably, slack and unjust rules breed other injustices. The latest is the astonishingly irrelevant setting of targets. The authorities now set targets for the number of confiscation orders to be made in any geographical area of the country and for the global amount they should be seeking in compensation. How conceivably can that be called justice?

So complicated and foreign to British practitioners are the concepts and language of this confiscation legislation that, in the words of the authors of one recent text-book on the subject, "the appeal courts have continued to be occupied in producing almost weekly judgements - most are significant, many are unreported, and some are irreconcilable." Another well-regarded commentator writes of the impression being given that "some prosecuting authorities have abandoned any pretence of fulfilling a 'minister of justice' role in favour of taking full advantage of what they appear to see as a revenue-raising racket.”

To add insult to so much injury, those who allocate fees to the publicly-funded criminal Bar have decided that this section of the law is in future to be only worthy of half the already grossly inadequate fees paid for the rest of the criminal work: so barristers will not do the work and the courts will have increasing difficulty in dealing with these cases at all.

\section{WHY?}

How has this legally complicated, draconian and unjust system come about? It is, I think, mainly because Parliament does not spend enough time, or use enough care, in vetting the laws put before it by civil servants and politicians - goaded on as they are by the tabloid press with little understanding of the consequences of what they do.

But it is also, surely, because there are now too few practising lawyers in Parliament. It is now well nigh impossible for an MP to be also a lawyer practising daily in the courts. Looking after ever more demanding constituents, in this new technological century of the internet, e-mails and mobile phones, is quite enough of a full-time job. So the people who know most about the effect of the laws that are being passed, are no longer to be found in Parliament advising the government or the draughters of the legislation, or taking part themselves in the making of good laws.

It may also be because our judges either do not make representations to government about the failings of such laws, or, if they do so privately, they are singularly unsuccessful in persuading our masters of their folly!

Are there any lessons here for the criminal legal systems of other countries? Perhaps there are not, if these jurisdictions already have more just and more sensible systems for depriving crooks of their ill-gotten gains. If that is the case, then the UK should not be too proud to learn from them! Of one thing I am sure - that when considering the wide range of measures that must be employed if we are to disrupt, deter or even stop the organised crime that is costing us 3 per cent of our nation's GDP (a sum approaching $£ 40$ billion a year), a law which is so contemptuous of our traditional ethical standards of justice should not be one of them.

Perhaps - or am I dreaming - the next Conservative Government might be persuaded to do something, drawing on the benefit of experience from overseas systems, to ensure that criminals are deprived of their ill-gotten gains by means which are fair and just, thereby removing this blot on the UK's reputation as a nation whose laws attain only the highest standards.

\section{Sir Ivan Lawrence QC}

The author was a Member of Parliament for 23 years, and chaired the Home Affairs Select Committee dealing with issues of Law and Order for five years. A Queen's Counsel for 27 years, and a Recorder of the Crown Courts for 19 years, he practises at the Criminal Bar. 